\title{
Functional Properties of Bamboo and Tencel Union Fabrics
}

\author{
Renuka Medar* and Geeta Mahale \\ Department of Textile and Apparel Designing, College of Community Science \\ University of Agricultural Sciences, Dharwad, India \\ *Corresponding author
}

\begin{abstract}
A B S T R A C T
Clothing being an essential need of our routine life thus, making fashion brands move more towards eco-friendly fabrics. World of textiles continues to break new grounds with innovative fibres like Cotton, Silk, Jute and Bamboo which are on rise and are fresh sustainable and bio degradable fibres, explored to the world of fashion. Bamboo a perennial plant grown in many parts of Asia, Africa and American continents and Tencel a new fibre obtained from woody plants both being an ecofriendly and user-friendly fibres of $21^{\text {st }}$ century adds more value to the trending era of textile designing. Hence an attempt is made to study the functional properties of Bamboo and Tencel union fabrics. Results revealed, Tencel union fabrics possessed good stiffness, crease recovery and drapability. Despite the fact that cotton fabric obtained good tensile strength and elongation however making union fabrics more resistant to abrasion. Bamboo union fabrics achieved better thermal insulation and air permeability providing more comfort when worn next to skin. Based on the fabric structure, handle properties it was found Bamboo and Tencel union fabrics being coarser and stiffer were more suitable for home furnishings. Introducing innovative yarns like Bamboo and Tencel in weaving not only adds value to the developed fabrics but also enhances its functionality and extends its durability giving more comfort to the wearer. Bamboo and Tencel both being obtained by regenerated process, own a very good medicinal value due to its hydrophilic feature thus can be utilized in medical textiles and also in sports wears.
\end{abstract}

\section{Keywords}

Cotton, Bamboo, Tencel, Union fabrics, Sustainable textiles

Article Info

Accepted:

30 May 2020

Available Online:

10 June 2020

\section{Introduction}

Clothing nowadays is no longer a material to be draped over human body for protection from extreme weather conditions. Rather it has many more functions like status symbol, beautifying agent, fitness guide, multitasking device and personality developer in an era of smart clothing. In order to enhance the functional features, introducing new fibres like bamboo and tencel improves the quality and durability of the fabrics produced. Bamboo is an evergreen perennial flowering plant belonging to subfamily Bambusoideae and grass family Poaceae. Bamboo fabrics are characterized by good hygroscopicity, excellent permeability, softer to feel, easy to straighten and dye. While Tencel is a brand name of Lyocell fibre, which is regenerated from cellulose extracted from eucalyptus 
wood pulp. The wood used for the purpose is, which is sustainably grown on farms in Europe, on land which is unsuitable for agriculture. Tencel fibre possesses great strength, excellent moisture management properties, and good absorbency and is gentle when worn next to skin. Tencel is soft, breathable, lightweight and comfortable, exceptionally strong fiber, both wet and dry conditions.

Bamboo fabrics are more prominent in bathrobes and towels, foot mats, bed clothes, intimate garments, Bamboo T-shirts, sanitary napkins and Bamboo socks and many others (Sarvanan and Prakash, 2008).

Tencel fabrics are widely used as sports wears, home furnishings, toweling materials and many other areas. Thus, with respect to the properties of both Bamboo and Tencel an attempt was made to study the functional properties of Bamboo and Tencel union fabrics.

\section{Materials and Methods}

\section{Procurement of raw material}

2/20s cotton yarns were procured from KHDC Gadag, Karnataka while Bamboo and Tencel yarns of 20s and 30s counts were procured from Pallava textiles, cotton mill, Mangarangam Palayam, Tamil Nadu.

\section{Design and development of union fabrics}

Weaving is the method of fabric production wherein, two sets of yarns are interlaced at right angles to each other. Two types of plain woven union fabrics were produced on a pit loom at Malali Village, Ramapur and Karnataka wherein cotton yarns were used as warp and Bamboo and Tencel yarns were used as weft.
Functional properties of Bamboo and Tencel union fabrics

\section{Cloth stiffness (cm)}

Cloth stiffness is the resistance of the fabric to bending. Bending length is the length of the fabric that bends under its own weight to a definite extent. It equals half the length of rectangular stripe of fabric that bends under its own weight to an angle of $41.5^{\circ}$. The test samples were tested as directed in BS test method: 3356-1961. A rectangular strip of fabric, 6 inch $\times 1$ inch was mounted on a horizontal platform in such a way that it hangs like a cantilever and bends downwards. Fabric was cut with help of template and then both template and fabric was placed on the platform with the fabric underneath. Both were pushed forward slowly. The strip of fabric was started to a droop over the edge of the platform and the movement of the templates and the fabric was continued until the tip of the fabric viewed in the mirror cuts both index lines. The bending length was read off from the scale mark opposite a zero line engraved on the side of the platform. Five readings were recorded by using Shirley's stiffness tester (Booth, 1996).

\section{Cloth crease recovery $\left(\right.$ Degrees $\left.^{\circ}\right)$}

Crease recovery is nothing but allowance of the fabric to recover from the crease. The test samples were tested as directed in IS method: 4681-1968 by using Shirley's crease recovery tester. Samples were cut both warp and weft way from the fabric with a template, 2 inch long by 1 inch wide. It was decreased by folding into half and placed under a weight of $2 \mathrm{~kg}$ for 5 minutes. The weight was removed and the specimen was transferred to the fabric clamp on the instrument using forceps and was allowed to recover from the crease for 5 minutes. As it recovered the dial of the instrument was rotated to keep the free edges 
of the specimen in line with the knife edge. At the end of the time period as it was allowed for recovery, usually 1 minute the recovery angle in degrees was read on the engraved scale. Readings were recorded for both warp and weft separately (Booth, 1996).

\section{Tensile strength (kgf) and elongation (\%)}

Tensile strength is the ability of the material to resist or rupture induced by eternal force. It is expressed as force per unit cross sectional area of the specimen at the time of maximum load. The specimens were tested as directed in ASTM test method: 12616-1989. The method employed to determine the breaking load and elongation of the material by using the 'raveled strip test' in Unistretch 250 tensile tester.

The fabric sample of $20 \mathrm{~cm} \times 5 \mathrm{~cm}$ dimensions was gripped between two clamps of the tensile testing machine in such a manner that the same fabric was gripped by both the clamps and a continuous increasing load was applied longitudinally to the specimen by moving one of the clamps until the specimen ruptured. Values of breaking load of the test specimen were recorded from the indicator of the machine.

Elongation is the increase in length of the specimen from its initial length expressed in units of length. The distance that material will extend under a given force is proportional to its original length. Hence elongation is coated as strain or percentage was assessed for the fabrics.

\section{Cloth drapability (\%)}

Drape is the ability of the fabric to assume a graceful appearance in us. Fabric drape may be explained as the extent to which a fabric deforms when it is allowed to hung under its own weight. A circular specimen about 10 inch diameter was supported on a circular disc about 5 inch diameter and upper supported area drapes over the edge. On switching the lamp of the drape meter, it gave the shadow of the draped area, which was taken on a paper and was weighed. Similarly draped shadow area of the template and supporting disc was also taken. Drape coefficient is the ratio of the projected area of the draped specimen to its undraped area after deduction of the area of the supporting disc.

\section{Cloth thermal insulation value (Tog)}

Thermal resistance is the ability of a material to resist the flow of heat. Thermal resistance is the reciprocal of thermal conductance i.e., lowering its value will raise the heat conduction and vice-versa. The specimens were tested manually. The experiment was carried out by cooling method. In this method, a hot body is wrapped with the fabric and its rate of cooling is measured. The outer surface of the fabric is exposed to the air. The experiment consists in finding the time taken by a hot body covered with the fabric sample without the sample to cool through a particular temperature range under identical atmospheric conditions. The experiment was started when temperature of the water was exactly $48^{\circ} \mathrm{C}$. A stop watch was used to find the time taken for the temperature to fall at $38^{\circ} \mathrm{C}$.

\section{Cloth Air permeability $\left(\mathrm{cm}^{3} / \mathrm{cm}^{2} / \mathrm{sec}\right)$}

Air permeability is defined as the volume of air measured in cubic centimeter passed per second through $1 \mathrm{~cm}^{2}$ of the fabric at a pressure of $1 \mathrm{~cm}$ of water. All the samples were tested as directed by ASTM D-737 test method. Air at standard atmosphere was drawn from laboratory through the test specimen by means of a suction pump, the rate of flow being controlled by means of the pass valve and service valve at the definite 
pressure. The rate of flow was adjusted until the required pressure drop across the fabric and is indicated on a draught gauge. The rate of flow of air was then recorded by rotameter from the instrument.

\section{Cloth abrasion resistance (Ratings)}

Cloth Abrasion is the rubbing away of component fibres and yarns of the fabric (Booth, 1996).

Abrasion resistance was carried out in digitized 'Martindale abrasion tester 'using IS 12673-1989 test method. Fabric specimens of $13.5 \mathrm{~cm}$ diameter were cut according to the size of template.

The specimens were abraded using zero emery paper and determination of end point was visualized until a hole was formed and number of cycles to create a hole and readings were recorded.

\section{Visual evaluation of bamboo and tencel union fabrics}

Visual assessment of the developed fabric was carried out by a panel of textile experts. Weighted average ranking (WAR) was done in order to study the preference of developed union fabrics based on rakings (5-Excellent, 4- Very good, 3-Good, 2- Fair and 1-Poor).

The cost of the yarns and developed bamboo and tencel union fabrics per meter were calculated for comparison of bamboo and tencel union fabrics.

\section{Statistical analysis}

The experimental data obtained from present experiment was subjected to two way ANOVA using two and three factorial designs using WINDOSTAT software developed by INDOSTAT services.

\section{Results and Discussion}

Table 1 highlights the physical properties of Cotton, Bamboo and Tencel yarns. It was observed that Cotton yarn obtained maximum yarn twist (16.84) compared to Bamboo (3.84) and Tencel (9.24) yarns of 30s counts which is due to the fibre content, the crystalinity of Cotton fibre which enhances the yarn to twist more, further adding strength. Similar results with respect to twist of Cotton yarns were obtained in a study on Effect of blend ratio on quality characteristics of Bamboo/Cotton blended ring spun yarn by Prakash et al., (2011).

Similarly Bamboo (8.2\%) and Tencel (8.4\%) yarns of 30s count possessed greatest amount of unevenness percentage (Thick, thin places and neps) which may be due to the presence of water in varying amounts or an uneven blend of two or more fibres will alter the relative permittivity (dielectric constant) in parts of the yarn and hence appear as unevenness. The results are on par with the study conducted by Majumdar et al., (2011) who concluded that, 100 per cent Cotton and Bamboo yarns have comparable yarn unevenness percentage. However, while in case of 30s bamboo yarn, the unevenness percentage was higher than that of $20 \mathrm{~s}$ bamboo yarn.

Bamboo 20s (922 no of hairs $/ \mathrm{km}$ ) yarn possessed highest yarn hairiness and length of hairs ranging from $3 \mathrm{~mm}$ to $15 \mathrm{~mm}$ which may be due to the yarn manufacturing, yarn production techniques. Higher yarn hairiness leads to faulty and poor quality of yarns that affects the thermal insulation and other apparel characteristics. Majumdar et al., (2011) reported that yarn hairiness of Bamboo were found to be higher than Cotton as Bamboo fibres are longer in length when compared to Cotton fibres. 
Likewise the count strength product was also seen higher in Cotton yarn (2954) because yarn count and yarn twist contributes to strength of the yarn which ultimately enhances the count strength product.

Single yarn strength of Cotton yarns (556.5 kgf) were found to be maximum when compared to Bamboo and Tencel yarns as the elastic nature of the cellulosic yarns makes them resistant to break when subjected to certain load applied. While Elongation was fond to be higher in case of Bamboo 20s yarn (9.1\%) compared to other yarns as Bamboo itself possessed good amount of waviness which makes a yarn to take more time to rupture as it lacks the plastic nature.

Lea yarn strength means the amount of pressure required to break a hank of yarn. Cotton yarn hank (152.6lbs) noticed greater lea yarn strength compared to Bamboo and Tencel yarns due to the friction of the pulleys on which the hanks were mounted and also the yarn friction. Yarn friction may alter the fibre constituent of the yarn and also the force at which the yarn initiates to break which depends on the type of instrument used. As the braking elongation of cotton fibres/yarn are expected to reach the rupture point earlier resulting in collapsing the entire yarn structure which makes the yarns unstable to take the load applied

Weaving is a technique of fabric construction wherein two sets of yarns viz., warp (lengthwise) and weft (filling) yarns are interlaced at right angle to each other to form a mesh like structure called as a woven fabric.

In the present research five different types of union fabrics were woven on a traditional handloom also called as 'pit loom' using 2/20s Cotton yarn were used as warp while Bamboo and Tencel yarns of 20s and 30s as weft. One control sample and four union fabrics were woven on a handloom with 72 ', reed width, cloth width of 36 " with 2 threads/dent denting order (Table 2).

Table 3 explains the constructional details of bamboo and tencel union fabrics wherein Cotton $\times$ Cotton $(\mathrm{CC})$, Cotton $\times$ Bamboo 20s $\left(\mathrm{CB}_{1}\right)$, Cotton $\times$ Bamboo 30s $\left(\mathrm{CB}_{2}\right)$, Cotton $\times$ Tencel 20s $\left(\mathrm{CT}_{1}\right)$, Cotton $\times$ Tencel 30s $\left(\mathrm{CT}_{2}\right)$ 2 ply yarns possessing $\mathrm{Z}$ twist were utilized to weave plain woven fabrics on a pit loom following a traditional style of weaving by master weaver in Malali Village, near Hubli.

Table 4 and Figure 1 disclose the cloth stiffness was slightly higher in union fabrics viz., Cotton $\times$ Tencel $20 \mathrm{~s}(6.40 \mathrm{~cm})$ and Cotton $\times$ Bamboo 20s $(5.92 \mathrm{~cm})$ fabric compared to Cotton $\times$ Cotton $(4.24 \mathrm{~cm})$ fabric in warp direction which is due to the sizing applied to warp yarns (Cotton yarns) prior to weaving thus imparting stiffness in warp direction. Whereas, due to the variation in the linear densities of the yarns, as tencel obtained greater single yarn strength (Table 1) resulted in higher stiffness which means if the fabric is stiffer, thus, it will take greater time to bend against gravity hence Cotton $\times$ Tencel fabrics had higher cloth stiffness in weft direction. Rashmi (2016) quoted warp way cloth stiffness was significantly lower than the weft way cloth stiffness as presence of cotton yarns which possessed finer yarn count and more evenness of the yarn.

It is perceived from table 5 and figure 2 that, among the fabrics Cotton $\times$ Bamboo 30s union fabric $\left(85.80^{\circ}\right)$ had highest crease recovery angle when compared to Cotton $\times$ Bamboo 20s $\left(83.40^{\circ}\right)$ and Cotton $\times$ Tencel $30 \mathrm{~s}\left(83.60^{\circ}\right)$ union fabric due to the combination of Cotton, Bamboo and Tencel yarns in union fabrics, more unevenness of the yarns, type of weave all alters the crease recovery angle in warp way. 
Weft way crease recovery was higher in Cotton $\times$ Bamboo 20s union fabric $\left(108.20^{\circ}\right)$ when compared to Cotton $\times$ Cotton fabric. This may be due to the stiffness of the union fabrics makes them more stiff and pliable than the control sample. The results were on par with the study on value addition to silk floss by Rashmi (2016).

Maximum tensile strength was observed in Cotton $\times$ Cotton fabric (38kgf) when compared to union fabrics which may be due to the presence of good amount of crysatllinity in the polymer system of both Cotton and Tencel which makes them to withstand the force applied to tear the fabric. However, Cotton $\times$ Tencel $(39.10 \mathrm{kgf}$ ) and Cotton $\times$ Bamboo (27.32kgf) 30s union fabric attained highest tensile strength in weft direction may be due to the combination of bamboo and tencel yarns with cotton yarns together influences the cloth tensile strength (Table 6 and Fig. 3).

Further, Cotton $\times$ Cotton fabric $(12.33 \%)$ possessed highest elongation percentage in warp direction on the other hand, Cotton $\times$ Tencel 20s union fabric (17.28\%) obtained highest elongation percentage in weft direction which as in case of cotton $\times$ cotton fabric both set of yarns are cotton which makes the fabric double times stronger while in case of Cotton $\times$ Tencel 20s union fabric both Cotton and Tencel yarn possess high amount of crysatalinity thus making the fabric stronger and sustain more pressure. Similar results were quoted by Rashmi (2016) in a study on value addition to silk floss and stated that in general warp way tensile strength of the designed fabric samples depicted higher tenacity.

Cloth drapability and stiffness are interrelated and are influenced by various properties viz., fabric set ratio, weave, cloth count and cloth thickness. Thus Table 7 and fig. 4 illustrates that, cloth drape coefficient was found to be higher in cotton $\times$ cotton fabric $(105.44 \%)$ and cotton $\times$ tencel $30 \mathrm{~s}$ union fabrics (104.11\%) which may be because of as cloth stiffness and cloth crease recovery of the fabrics were found to be on par when compare to cotton $\times$ bamboo union fabric resulting in higher stiffness ultimately making a fabric stiffer and coarser.

However, irrespective of counts, least cloth drape coefficient was found in cotton $x$ bamboo/tencel union fabrics contributing to lower bending length and cloth thickness, thus making the fabric more supple and soft. Least cloth drape coefficient attributed to low cloth stiffness thus making it soft and pliable (Kulkarni et al., 2011).

Table 8 and Figure 5 indicated that, Cotton $\times$ Cotton (5) and cotton $\times$ bamboo 20s union fabric exhibited no pilling, indicating excellent durability of the fabric thus increasing its life for longer usage. The factors contributing to abrasion resistance are yarn count, cloth count, cloth thickness and the amount of friction between the abradent used and the fabric surface. The results of value addition to silk floss by Rashmi (2016) were on par with present research stating that union fabrics with cotton $\times$ cotton/silk floss depicted higher abrasion resistance due to the higher percentage of cotton fibre also depends on yarn count, thickness, cloth count and highest contact with abradent and fabric surface.

Table 9 and figure 6 expresses that the cloth thermal insulation value depicted higher in cotton $\times$ bamboo 20s union fabric (29.60 tog) when compared to the cotton $\times$ cotton fabric (27.34 tog) because as cotton is a good conductor of heat, cotton and bamboo both being cellulosic in nature have the tendency to retain heat energy and combining the properties of both cotton and bamboo results 
in good thermal insulation value of the union fabrics. The results of value addition to silk floss by Rashmi (2016) were on par, stating that, maximum thermal insulation value was observed in union fabrics which were due to the combined effect of cotton and silk floss resulting in higher thickness

Table.1 Physical properties of Cotton, Bamboo and Tencel yarns

\begin{tabular}{|c|c|c|c|c|c|c|c|c|c|}
\hline \multirow[t]{2}{*}{ Sl.No } & \multirow{2}{*}{$\begin{array}{l}\text { Type of } \\
\text { Yarn }\end{array}$} & \multicolumn{8}{|c|}{ Yarn parameters } \\
\hline & & Count & Twist & $\begin{array}{c}\text { Unevenness } \\
(\%)\end{array}$ & $\begin{array}{c}\text { Hairiness } \\
\text { (No. of } \\
\text { hairs/km) }\end{array}$ & $\begin{array}{l}\text { Count } \\
\text { Strength } \\
\text { Product }\end{array}$ & $\begin{array}{c}\text { Single } \\
\text { yarn } \\
\text { Strength } \\
\text { (kgf) }\end{array}$ & $\begin{array}{c}\text { Elongation } \\
(\%)\end{array}$ & $\begin{array}{c}\text { Lea } \\
\text { yarn } \\
\text { strength } \\
\text { (lbs) }\end{array}$ \\
\hline 1 & Cotton & 20 & 16.84 & 8.0 & 246 & 2954 & 556.5 & 4.5 & 152.6 \\
\hline \multirow[t]{2}{*}{2} & \multirow[t]{2}{*}{ Bamboo } & 20 & 3.26 & 8.0 & 922 & 1540 & 166.4 & 9.1 & 78.2 \\
\hline & & 30 & 3.84 & 8.2 & 303 & 1373 & 132.6 & 8.4 & 46.5 \\
\hline \multirow[t]{2}{*}{3} & \multirow[t]{2}{*}{ Tencel } & 20 & 4.84 & 7.6 & 307 & 2948 & 447.4 & 6.6 & 143.2 \\
\hline & & 30 & 9.24 & 8.4 & 340 & 2611 & 287.7 & 6.1 & 87.78 \\
\hline
\end{tabular}

Table.2 Loom particulars of Bamboo and Tencel union fabrics

\begin{tabular}{|c|l|c|}
\hline Sl. No. & \multicolumn{1}{|c|}{ Particulars } & $\begin{array}{c}\text { Union fabrics } \\
\left(\mathbf{C C} / \mathbf{C B}_{1} / \mathbf{C B}_{2} / \mathbf{C T}_{\mathbf{1}} / \mathbf{C T}_{\mathbf{2}}\right)\end{array}$ \\
\hline $\mathbf{1 .}$ & Type of loom & Pit loom $($ Handloom $)$ \\
\hline $\mathbf{2 .}$ & Reed width & $\mathbf{7 2}{ }^{\prime \prime}$ \\
\hline $\mathbf{3 .}$ & Cloth width & $36^{\prime}$ \\
\hline $\mathbf{4 .}$ & Denting order & 2 Threads/dent \\
\hline
\end{tabular}

Table.3 Constructional details of Bamboo and Tencel union fabrics

\begin{tabular}{|c|c|c|c|c|c|c|c|}
\hline $\begin{array}{l}\text { Sl. } \\
\text { No. }\end{array}$ & Union fabrics & Direction & $\begin{array}{c}\text { Fiber } \\
\text { Content }\end{array}$ & $\begin{array}{c}\text { Yarn } \\
\text { type }\end{array}$ & $\begin{array}{c}\text { Twist } \\
\text { Direction }\end{array}$ & $\begin{array}{l}\text { Threads } \\
\text { per inch }\end{array}$ & Weave \\
\hline \multirow[t]{2}{*}{1} & \multirow[t]{2}{*}{ Cotton $\times$ Cotton } & Warp & Cotton & \multirow{10}{*}{2 Ply } & $\mathrm{Z}$ & 48 & \multirow[t]{2}{*}{ Plain } \\
\hline & & Weft & Cotton & & $\mathrm{Z}$ & 26 & \\
\hline \multirow[t]{2}{*}{2} & \multirow[t]{2}{*}{ Cotton $\times$ Bamboo 20s } & Warp & Cotton & & $\mathrm{Z}$ & 51 & \multirow[t]{2}{*}{ Plain } \\
\hline & & Weft & Bamboo & & $\mathrm{Z}$ & 23 & \\
\hline \multirow[t]{2}{*}{3} & \multirow[t]{2}{*}{ Cotton $\times$ Bamboo 30s } & Warp & Cotton & & $\mathrm{Z}$ & 50 & \multirow[t]{2}{*}{ Plain } \\
\hline & & Weft & Bamboo & & $\mathrm{Z}$ & 26 & \\
\hline \multirow[t]{2}{*}{4} & \multirow[t]{2}{*}{ Cotton $\times$ Tencel 20s } & Warp & Cotton & & $\mathrm{Z}$ & 50 & \multirow[t]{2}{*}{ Plain } \\
\hline & & Weft & Tencel & & $\mathrm{Z}$ & 23 & \\
\hline \multirow[t]{2}{*}{5} & \multirow[t]{2}{*}{ Cotton $\times$ Tencel 30s } & Warp & Cotton & & $\mathrm{Z}$ & 50 & \multirow[t]{2}{*}{ Plain } \\
\hline & & Weft & Tencel & & $\mathrm{Z}$ & 27 & \\
\hline
\end{tabular}


Table.4 Cloth stiffness of Bamboo and Tencel union fabrics

\begin{tabular}{|c|l|c|c|}
\hline & & \multicolumn{2}{|c|}{ Cloth stiffness $(\mathbf{c m})$} \\
\cline { 3 - 4 } Sl. No. & Union fabrics & Warp & Weft \\
\hline $\mathbf{1 .}$ & Cotton $\times$ Cotton & $\mathbf{4 . 2 4}$ & 1.82 \\
\hline 2. & Cotton $\times$ Bamboo $20 \mathrm{~s}$ & $\mathbf{5 . 9 2}$ & 1.74 \\
\hline 3. & Cotton $\times$ Bamboo $30 \mathrm{~s}$ & 2.64 & $\mathbf{1 . 8 6}$ \\
\hline $\mathbf{4 .}$ & Cotton $\times$ Tencel $20 \mathrm{~s}$ & $\mathbf{6 . 4 0}$ & $\mathbf{1 . 8 6}$ \\
\hline $\mathbf{5 .}$ & Cotton $\times$ Tencel $30 \mathrm{~s}$ & 4.04 & $\mathbf{1 . 9 2}$ \\
\hline
\end{tabular}

\begin{tabular}{|l|c|c|}
\hline \multicolumn{2}{|c|}{ ANOVA Table } \\
\hline \multicolumn{1}{|c|}{ Factors } & $\begin{array}{c}\text { S.Em. } \\
\pm\end{array}$ & C.D. (5 \%) \\
\hline A- (Union fabrics) & 0.04 & 0.12 \\
\hline B- (Warp and weft) & 0.02 & 0.07 \\
\hline A $\times$ B- (Union fabrics) $\times$ (warp and weft) & 0.06 & 0.17 \\
\hline
\end{tabular}

* CD- Critical difference

Table.5 Cloth crease recovery of Bamboo and Tencel union fabrics

\begin{tabular}{|c|l|c|c|}
\hline \multirow{2}{*}{$\begin{array}{c}\text { Sl. } \\
\text { No. }\end{array}$} & \multicolumn{1}{|c|}{ Union fabrics } & \multicolumn{2}{|c|}{$\begin{array}{c}\text { Cloth crease recovery } \\
\text { (degrees) }\end{array}$} \\
\hline 1. & Cotton $\times$ Cotton & Warp & Weft \\
\hline 2. & Cotton $\times$ Bamboo 20s & 82.40 & 84.20 \\
\hline 3. & Cotton $\times$ Bamboo 30s & $\mathbf{8 5 . 8 0}$ & $\mathbf{1 0 8 . 2 0}$ \\
\hline 4. & Cotton $\times$ Tencel 20s & 56.40 & 106.00 \\
\hline 5. & Cotton $\times$ Tencel 30s & 83.60 & 99.20 \\
\hline
\end{tabular}

ANOVA Table

\begin{tabular}{|l|c|c|}
\hline \multicolumn{1}{|c|}{ Factors } & S.Em. & C.D. (5 \%) \\
& \pm & \\
\hline A- (Union fabrics) & 1.24 & 3.55 \\
\hline B-(Warp and weft) & 0.78 & 2.24 \\
\hline A $\times$ B- (Union fabrics) $\times$ (warp and weft) & 1.75 & 5.02 \\
\hline
\end{tabular}

$*$ CD- Critical difference

Table.6 Cloth tensile strength and elongation of Bamboo and Tencel union fabrics

\begin{tabular}{|c|l|c|c|c|c|}
\hline Sl. No. & \multicolumn{1}{|c|}{ Union fabrics } & \multicolumn{2}{|c|}{ Tensile strength (kgf) } & \multicolumn{2}{c|}{ Elongation (\%) } \\
\cline { 3 - 6 } & & Warp & Weft & Warp & Weft \\
\hline 1. & Cotton $\times$ Cotton & $\mathbf{3 8 . 0 0}$ & 25.24 & $\mathbf{1 2 . 3 3}$ & 11.51 \\
\hline 2. & Cotton $\times$ Bamboo 20s & 30.02 & 18.76 & 9.66 & 16.76 \\
\hline 3. & Cotton $\times$ Bamboo 30s & 36.72 & $\mathbf{2 7 . 3 2}$ & 12.01 & 8.23 \\
\hline 4. & Cotton $\times$ Tencel 20s & 37.1 & 21.70 & 10.44 & $\mathbf{1 7 . 2 8}$ \\
\hline $\mathbf{5 .}$ & Cotton $\times$ Tencel 30s & 34.66 & $\mathbf{3 9 . 1}$ & 12.10 & 11.33 \\
\hline
\end{tabular}


ANOVA Table

\begin{tabular}{|c|c|c|}
\hline Factors & S.Em. \pm & $\begin{array}{c}\text { C.D }(5 \\
\%)\end{array}$ \\
\hline A- (Union fabrics) & 0.22 & $0.63 *$ \\
\hline B- (Tensile strength and elongation) & 0.14 & $0.39 *$ \\
\hline C- (Warp and weft) & 0.14 & $0.39 *$ \\
\hline $\begin{array}{l}\text { A } \times \text { B }-(\text { Union fabrics }) \times(\text { tensile strength and } \\
\text { elongation) }\end{array}$ & 0.31 & $0.89 *$ \\
\hline$A \times C-($ Union fabrics $) \times($ warp and weft $)$ & 0.31 & $0.89 *$ \\
\hline $\begin{array}{l}B \times C-(\text { Tensile strength and elongation }) \times(\text { warp and } \\
\text { weft })\end{array}$ & 0.20 & $0.56^{*}$ \\
\hline $\begin{array}{l}A \times B \times C-(\text { Union fabrics }) \times(\text { tensile strength and } \\
\text { elongation }) \times(\text { warp and weft })\end{array}$ & 0.44 & $1.32 *$ \\
\hline
\end{tabular}

*-CD-Critical difference; Significant at $5 \%$ level of significance

Table.7 Cloth drapability of Bamboo and Tencel union fabrics

\begin{tabular}{|c|l|c|c|}
\hline SI. No. & \multicolumn{1}{|c|}{ Union fabrics } & No of nodes & Drape coefficient $(\mathbf{\%})$ \\
\hline $\mathbf{1 .}$ & Cotton $\times$ Cotton & 3 & $\mathbf{1 0 5 . 4 4}$ \\
\hline $\mathbf{2 .}$ & Cotton $\times$ Bamboo 20s & 3 & 97.30 \\
\hline 3. & Cotton $\times$ Bamboo 30s & 4 & 95.24 \\
\hline 4. & Cotton $\times$ Tencel 20s & 4 & 101.31 \\
\hline $\mathbf{5 .}$ & Cotton $\times$ Tencel 30s & 4 & $\mathbf{1 0 4 . 1 1}$ \\
\hline
\end{tabular}

ANOVA Table

\begin{tabular}{|l|c|c|}
\hline \multicolumn{1}{|c|}{ Factors } & S.Em. \pm & C.D. (5 \%) \\
\hline A- (Union fabrics) & 0.55 & $1.58^{*}$ \\
\hline B- (No of nodes and drape coefficient) & 0.35 & $1.00^{*}$ \\
\hline $\begin{array}{l}\text { A } \times \text { B- (Union fabrics) } \\
\text { coefficient) }\end{array}$ & 0.78 & $2.23^{*}$ \\
\hline
\end{tabular}

*- CD- Critical difference; Significant at $5 \%$ level of significance

Table.8 Cloth abrasion resistance of Bamboo and Tencel union fabrics

\begin{tabular}{|c|l|c|c|}
\hline SI. No. & \multicolumn{1}{|c|}{ Union fabrics } & Total revolution & $\begin{array}{c}\text { Cloth abrasion } \\
\text { resistance }\end{array}$ \\
\hline 1. & Cotton $\times$ Cotton & 100 & $\mathbf{5}$ \\
\hline 2. & Cotton $\times$ Bamboo 20s & Revolutions/ Sample & 4 \\
\hline 3. & Cotton $\times$ Bamboo 30s & & $\mathbf{5}$ \\
\hline 4. & Cotton $\times$ Tencel 20s & & 4 \\
\hline 5. & Cotton $\times$ Tencel 30s & & 4 \\
\hline
\end{tabular}

5- No pilling, 4- Slight pilling, 3- Moderate Pilling, 2- Severe pilling, 1- Very severe pilling 
Table.9 Cloth thermal insulation value of Bamboo and Tencel union fabrics

\begin{tabular}{|c|l|c|}
\hline Sl. No. & \multicolumn{1}{|c|}{ Union fabrics } & $\begin{array}{c}\text { Cloth thermal insulation value } \\
(\mathbf{t o g})\end{array}$ \\
\hline $\mathbf{1 .}$ & Cotton $\times$ Cotton & 27.34 \\
\hline $\mathbf{2 .}$ & Cotton $\times$ Bamboo 20s & $\mathbf{2 9 . 6 0}$ \\
\hline $\mathbf{3 .}$ & Cotton $\times$ Bamboo 30s & 23.84 \\
\hline $\mathbf{4 .}$ & Cotton $\times$ Tencel 20s & 27.42 \\
\hline $\mathbf{5 .}$ & Cotton $\times$ Tencel 30s & 26.34 \\
\hline & S.Em. \pm & 0.01 \\
\hline & C.D. 5 \% & $0.03 *$ \\
\hline
\end{tabular}

Table.10 Cloth air permeability of cotton $\times$ bamboo/tencel union fabrics

\begin{tabular}{|c|c|c|}
\hline Sl. No. & Union fabrics & $\begin{array}{l}\text { Cloth air permeability } \\
\left(\mathrm{cm}^{3} / \mathrm{cm}^{2} / \mathrm{sec}\right)\end{array}$ \\
\hline 1. & Cotton $\times$ Cotton & 58.32 \\
\hline 2. & Cotton $\times$ Bamboo $20 \mathrm{~s}$ & 43.38 \\
\hline 3. & Cotton $\times$ Bamboo 30s & 76.26 \\
\hline 4. & Cotton $\times$ Tencel 20s & 69.28 \\
\hline 5. & Cotton $\times$ Tencel $30 \mathrm{~s}$ & 75.28 \\
\hline & S.Em. \pm & 0.01 \\
\hline & C.D. $5 \%$ & $0.03 *$ \\
\hline
\end{tabular}

*-CD-Critical difference; Significant at $5 \%$ level of significance

Table.11 Textile expert's opinion on fabric structure and tactile properties of developed union fabrics

\begin{tabular}{|c|c|c|c|c|c|c|c|c|c|}
\hline \multirow{2}{*}{$\begin{array}{l}\text { Sl. } \\
\text { No }\end{array}$} & \multirow[t]{2}{*}{ Samples } & \multicolumn{2}{|c|}{ Fabric structure } & \multicolumn{2}{|c|}{ Fabric texture } & \multicolumn{4}{|c|}{ Fabric handle } \\
\hline & & $\begin{array}{c}\text { Loosely } \\
\text { woven }\end{array}$ & $\begin{array}{c}\text { Compactly } \\
\text { woven }\end{array}$ & Smooth & Rough & $\begin{array}{c}\text { Soft/ } \\
\text { flexible }\end{array}$ & Coarse/stiff & $\begin{array}{l}\text { Soft/ } \\
\text { Stiff }\end{array}$ & $\begin{array}{l}\text { Coarse/ } \\
\text { flexible }\end{array}$ \\
\hline 1 & $\begin{array}{l}\text { Cotton } x \\
\text { Cotton }\end{array}$ & $\begin{array}{c}20 \\
(\mathbf{8 0 . 0 0})\end{array}$ & $\begin{array}{c}5 \\
(20.00)\end{array}$ & $\begin{array}{c}4 \\
(16.00)\end{array}$ & $\begin{array}{c}21 \\
(84.00)\end{array}$ & $\begin{array}{c}5 \\
(20.00)\end{array}$ & $\begin{array}{c}7 \\
(28.00)\end{array}$ & $\begin{array}{c}2 \\
(8.00)\end{array}$ & $\begin{array}{c}11 \\
(44.00)\end{array}$ \\
\hline 2 & $\begin{array}{l}\text { Cotton } x \\
\text { Bamboo } \\
20 s\end{array}$ & $\begin{array}{c}19 \\
(76.00)\end{array}$ & $\begin{array}{c}6 \\
(24.00)\end{array}$ & 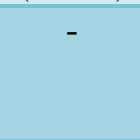 & $\begin{array}{c}25 \\
(100.00)\end{array}$ & $\begin{array}{c}1 \\
(4.00)\end{array}$ & $\begin{array}{c}11 \\
(44.00)\end{array}$ & $\begin{array}{c}1 \\
(4.00)\end{array}$ & $\begin{array}{c}12 \\
(48.00)\end{array}$ \\
\hline 3 & $\begin{array}{l}\text { Cotton } \times \\
\text { Bamboo } \\
30 s\end{array}$ & $\begin{array}{c}17 \\
(68.00)\end{array}$ & $\begin{array}{c}8 \\
(32.00)\end{array}$ & $\begin{array}{c}5 \\
(20.00)\end{array}$ & $\begin{array}{c}20 \\
(80.00)\end{array}$ & $\begin{array}{c}21 \\
(84.00)\end{array}$ & $\begin{array}{c}3 \\
(12.00)\end{array}$ & $\begin{array}{c}1 \\
(4.00)\end{array}$ & - \\
\hline 4 & $\begin{array}{l}\text { Cotton } \times \\
\text { Tencel 20s }\end{array}$ & $\begin{array}{c}18 \\
(72.00)\end{array}$ & $\begin{array}{c}7 \\
(28.00)\end{array}$ & $\begin{array}{c}2 \\
(8.00)\end{array}$ & $\begin{array}{c}23 \\
(92.00)\end{array}$ & $\begin{array}{c}4 \\
(16.00)\end{array}$ & $\begin{array}{c}8 \\
(32.00)\end{array}$ & $\begin{array}{c}1 \\
(4.00)\end{array}$ & $\begin{array}{c}12 \\
(48.00)\end{array}$ \\
\hline 5 & $\begin{array}{l}\text { Cotton } x \\
\text { Tencel } 30 \text { s }\end{array}$ & $\begin{array}{c}16 \\
(64.00)\end{array}$ & $\begin{array}{c}9 \\
(36.00)\end{array}$ & $\begin{array}{c}3 \\
(12.00)\end{array}$ & $\begin{array}{c}22 \\
(88.00)\end{array}$ & $\begin{array}{c}3 \\
(12.00)\end{array}$ & $\begin{array}{c}15 \\
(60.00)\end{array}$ & $\begin{array}{c}1 \\
(4.00)\end{array}$ & $\begin{array}{c}6 \\
(24.00)\end{array}$ \\
\hline
\end{tabular}


Table.12 Preference of the developed union fabrics by textile experts

\begin{tabular}{|c|c|c|c|c|c|c|c|c|}
\hline \multirow[t]{2}{*}{ Sl.No } & \multirow[t]{2}{*}{ Samples } & \multicolumn{7}{|c|}{ Bamboo and Tencel union fabrics } \\
\hline & & Excellent & $\begin{array}{l}\text { Very } \\
\text { good }\end{array}$ & Good & Fair & Poor & Average & WAR \\
\hline 1 & Cotton $\times$ Cotton & $\begin{array}{c}6 \\
(24.00) \\
\end{array}$ & $\begin{array}{c}5 \\
(20.00)\end{array}$ & $\begin{array}{c}7 \\
(28.00) \\
\end{array}$ & - & $\begin{array}{c}7 \\
(28.00)\end{array}$ & 3.12 & III \\
\hline 2 & Cotton $\times$ Bamboo 20s & $\begin{array}{c}11 \\
(44.00)\end{array}$ & - & $\begin{array}{c}8 \\
32.00)\end{array}$ & $\begin{array}{c}4 \\
(16.00)\end{array}$ & $\begin{array}{c}2 \\
(8.00)\end{array}$ & 3.56 & II \\
\hline 3 & Cotton $\times$ Bamboo 30s & $\begin{array}{c}4 \\
(16.00)\end{array}$ & $\begin{array}{c}12 \\
(48.00)\end{array}$ & $\begin{array}{c}5 \\
(20.00)\end{array}$ & $\begin{array}{c}3 \\
(12.00)\end{array}$ & $\begin{array}{c}1 \\
(4.00)\end{array}$ & 3.60 & $\mathbf{I}$ \\
\hline 4 & Cotton $\times$ Tencel 20s & $\begin{array}{c}2 \\
(8.00)\end{array}$ & $\begin{array}{c}6 \\
(24.00)\end{array}$ & $\begin{array}{c}3 \\
(12.00)\end{array}$ & $\begin{array}{c}11 \\
(44.00)\end{array}$ & $\begin{array}{c}3 \\
(12.00)\end{array}$ & 2.72 & IV \\
\hline 5 & Cotton $\times$ Tencel 30s & $\begin{array}{c}2 \\
(8.00)\end{array}$ & $\begin{array}{c}2 \\
(8.00)\end{array}$ & $\begin{array}{c}2 \\
(8.00)\end{array}$ & $\begin{array}{c}6 \\
(24.00)\end{array}$ & $\begin{array}{c}13 \\
(52.00)\end{array}$ & 1.96 & V \\
\hline
\end{tabular}

5 - Excellent 4 - Very good 3- Good 2- Fair 1- Poor

Figures in parenthesis indicate percentages

Table.13 Cost of production of developed union fabrics

\begin{tabular}{|c|c|c|c|c|c|c|}
\hline \multirow{2}{*}{$\begin{array}{l}\text { Sl. } \\
\text { No. }\end{array}$} & \multirow[t]{2}{*}{ Particulars } & \multirow{2}{*}{$\begin{array}{c}\text { Cotton } \\
\times \\
\text { Cotton }\end{array}$} & \multicolumn{4}{|c|}{ Union fabrics } \\
\hline & & & $\begin{array}{c}\text { Cotton } x \\
\text { Bamboo } \\
20 \mathrm{~s}\end{array}$ & $\begin{array}{c}\text { Cotton } \times \\
\text { Bamboo 30s }\end{array}$ & $\begin{array}{c}\text { Cotton } \times \\
\text { Tencel 20s }\end{array}$ & $\begin{array}{c}\text { Cotton } \times \\
\text { Tencel 30s }\end{array}$ \\
\hline I. & Variable & \multirow{2}{*}{\multicolumn{5}{|c|}{400.00}} \\
\hline \multirow[t]{2}{*}{$\mathbf{a}$} & $\begin{array}{l}\text { Cost } \\
\text { (Raw } \\
\text { material) } \\
\text { Warp }\end{array}$ & & & & & \\
\hline & Weft & 400.00 & \multicolumn{2}{|c|}{250.00} & \multicolumn{2}{|c|}{280.00} \\
\hline & Total & 800.00 & \multicolumn{2}{|c|}{650.00} & \multicolumn{2}{|c|}{680.00} \\
\hline b & $\begin{array}{l}\text { Pre } \\
\text { preparatory } \\
\text { process }\end{array}$ & \multicolumn{5}{|c|}{66.60} \\
\hline c & Weaving & \multicolumn{5}{|c|}{80.00} \\
\hline II. & $\begin{array}{l}\text { Total cost of } \\
\text { production }\end{array}$ & 946.6 & \multicolumn{2}{|c|}{796.6} & \multicolumn{2}{|c|}{826.6} \\
\hline
\end{tabular}

Cost of cotton yarn /kg (warp): Rs. 400.00/-

Cost of bamboo yarn (20s and 30s) kg (weft): Rs. 250.0/-

Cost of tencel yarn (20s and 30s) /kg (weft): Rs.280.00/- 


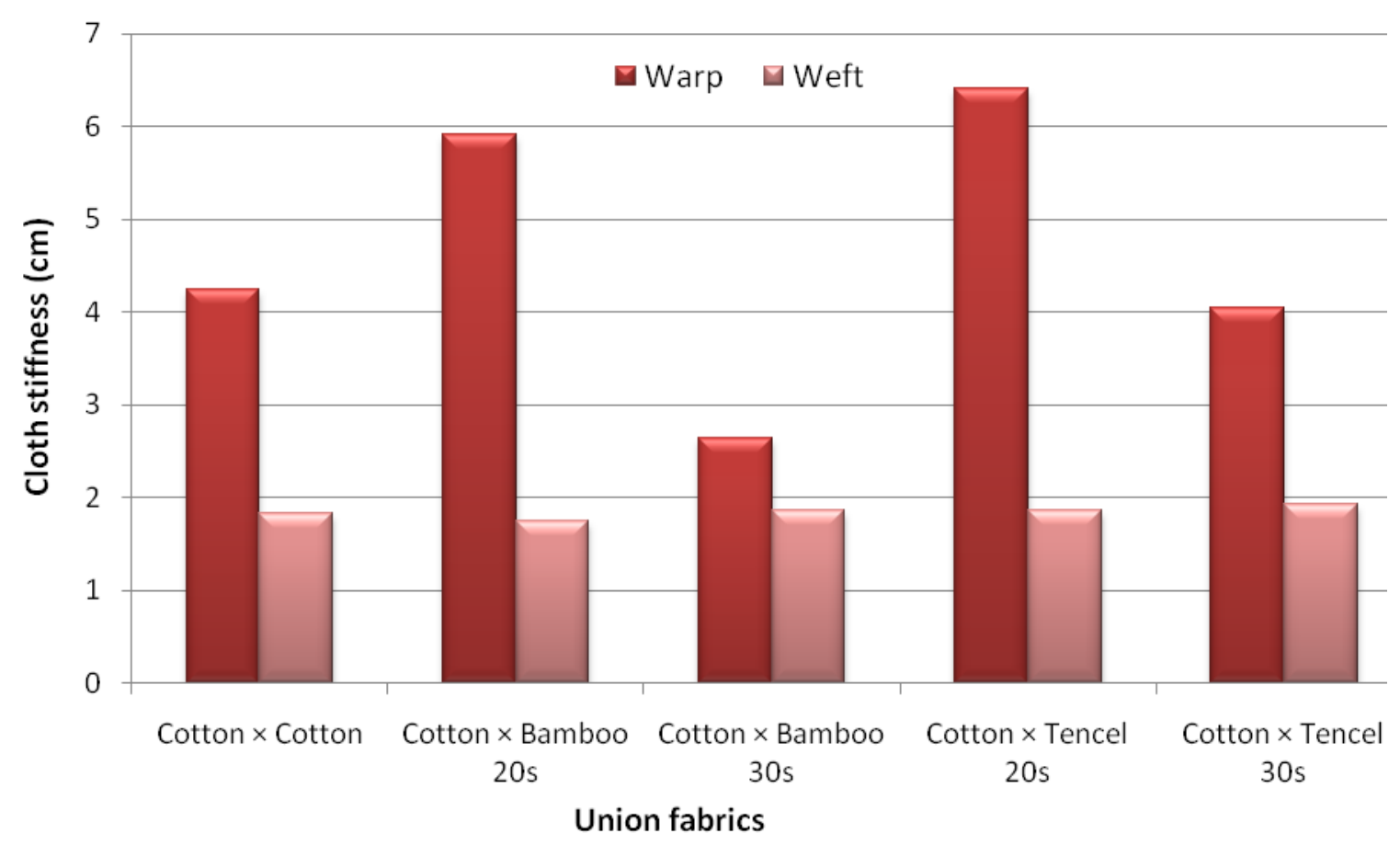

Fig 1: Cloth stiffness of Bamboo and Tencel union fabrics

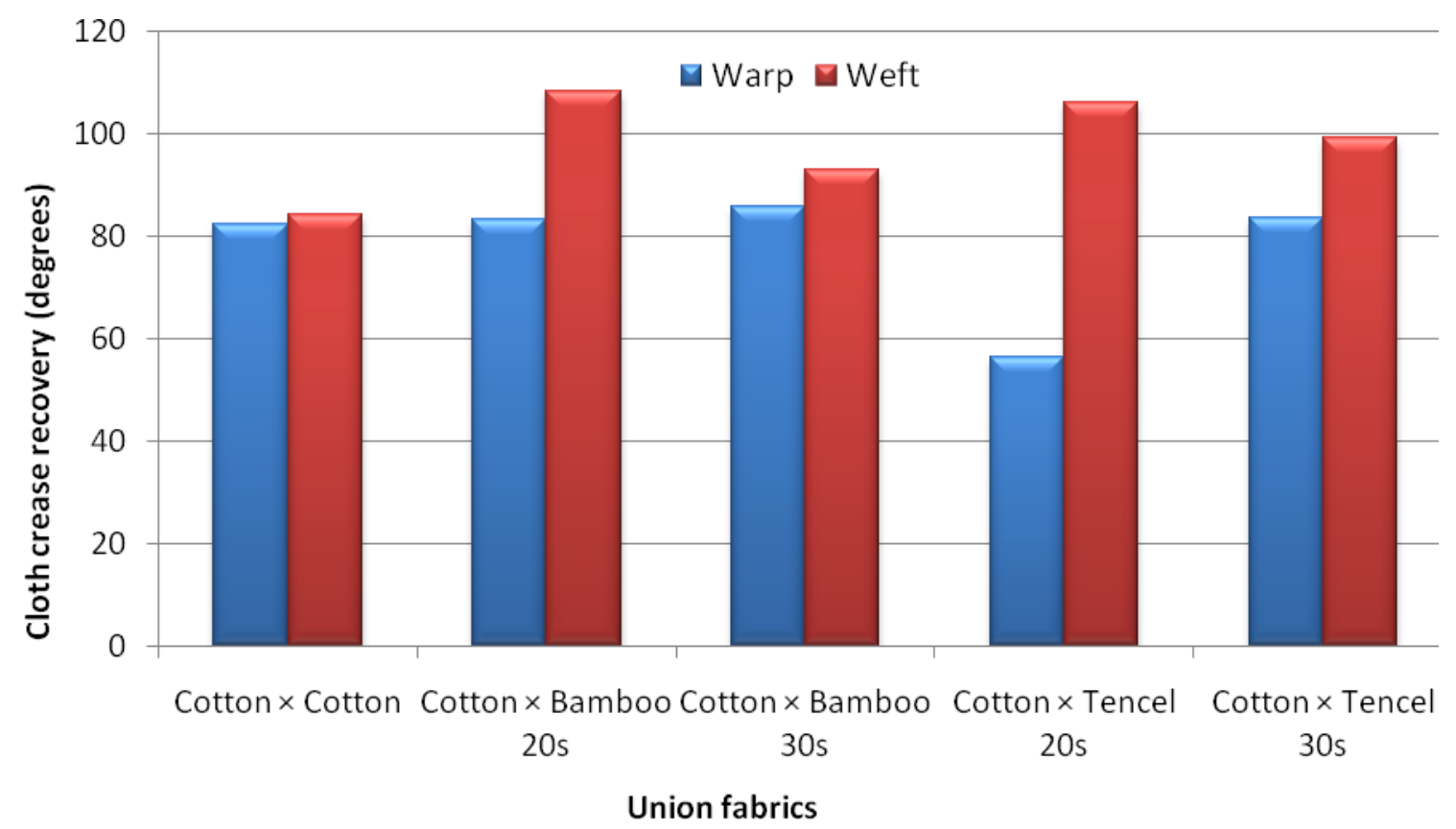

Fig 2: Cloth crease recovery of Bamboo and Tencel union fabrics 


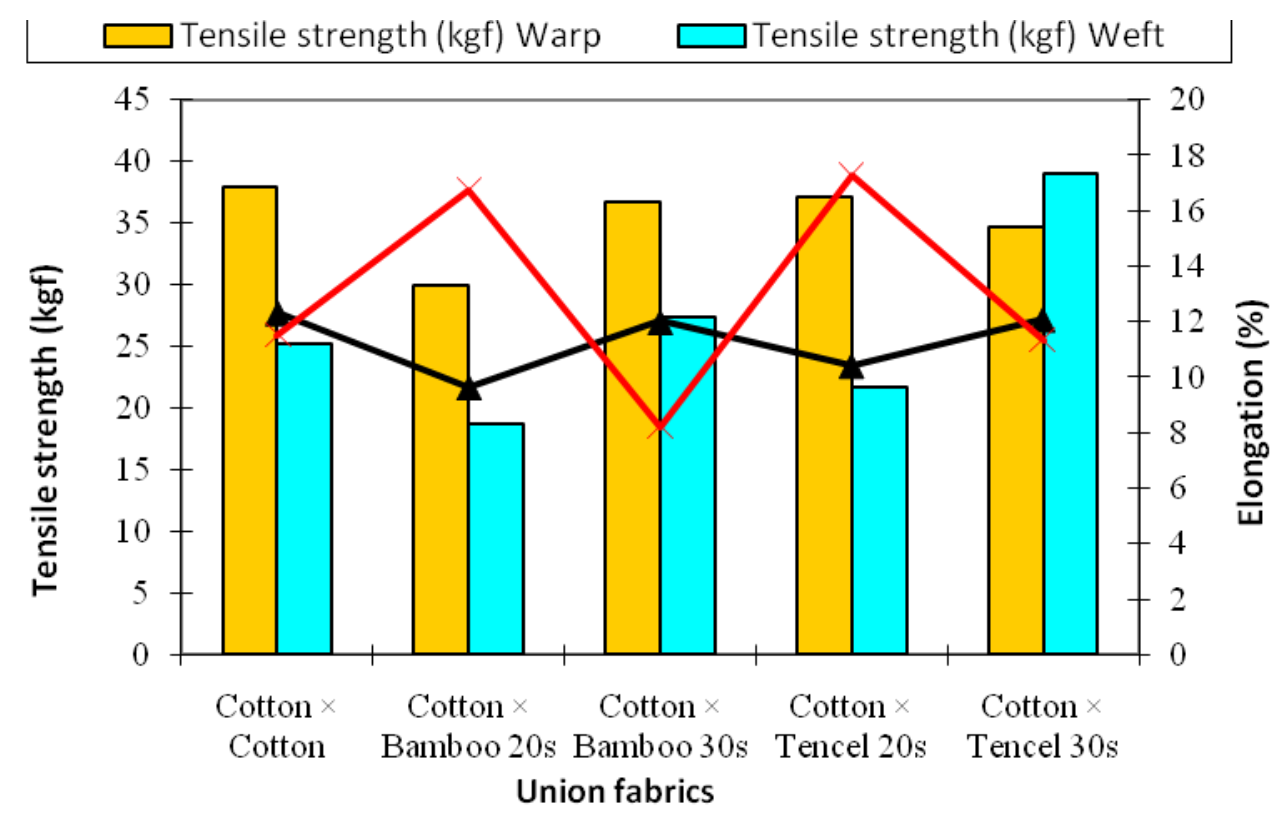

Fig 3 : Cloth tensile strength and elongation of Bamboo and Tencel union fabrics

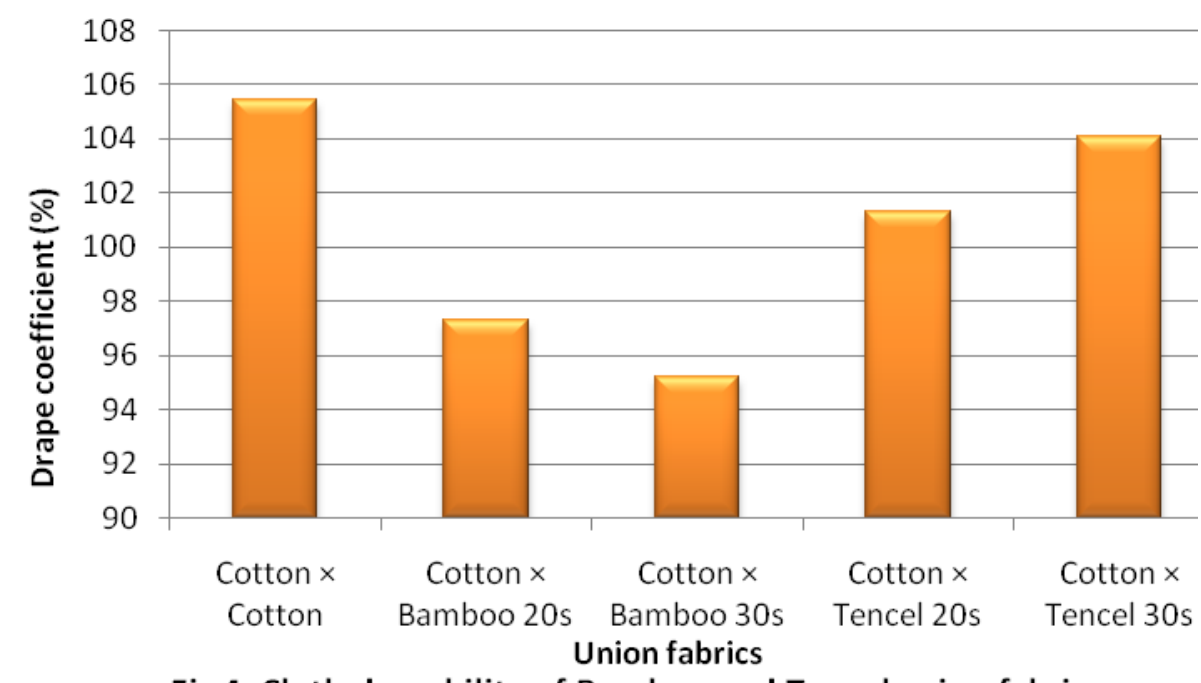

Fig 4: Cloth drapability of Bamboo and Tencel union fabrics 


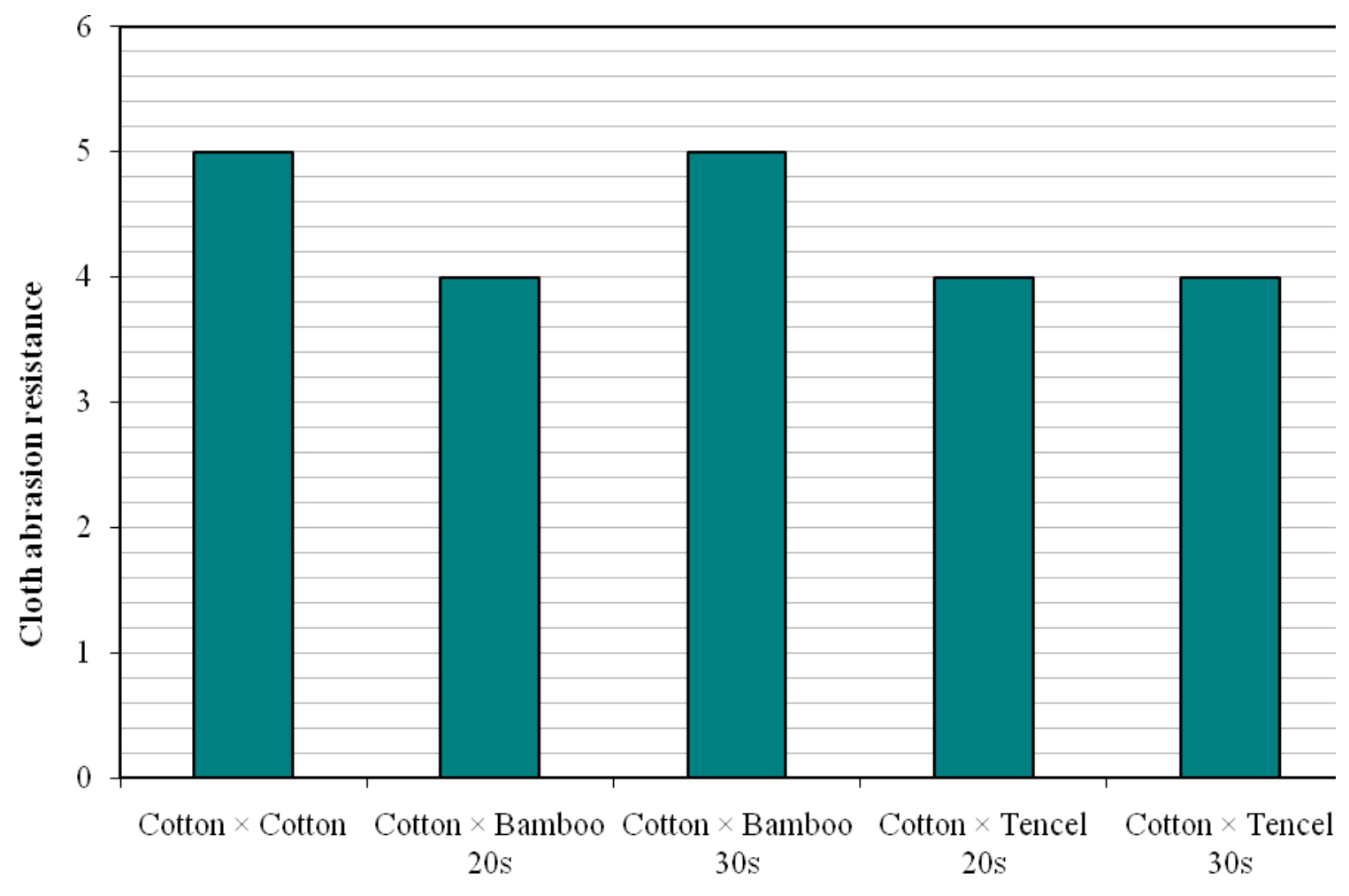

Union fabrics

Fig 5: Cloth abrasion resistance of Bamboo and Tencel union fabrics

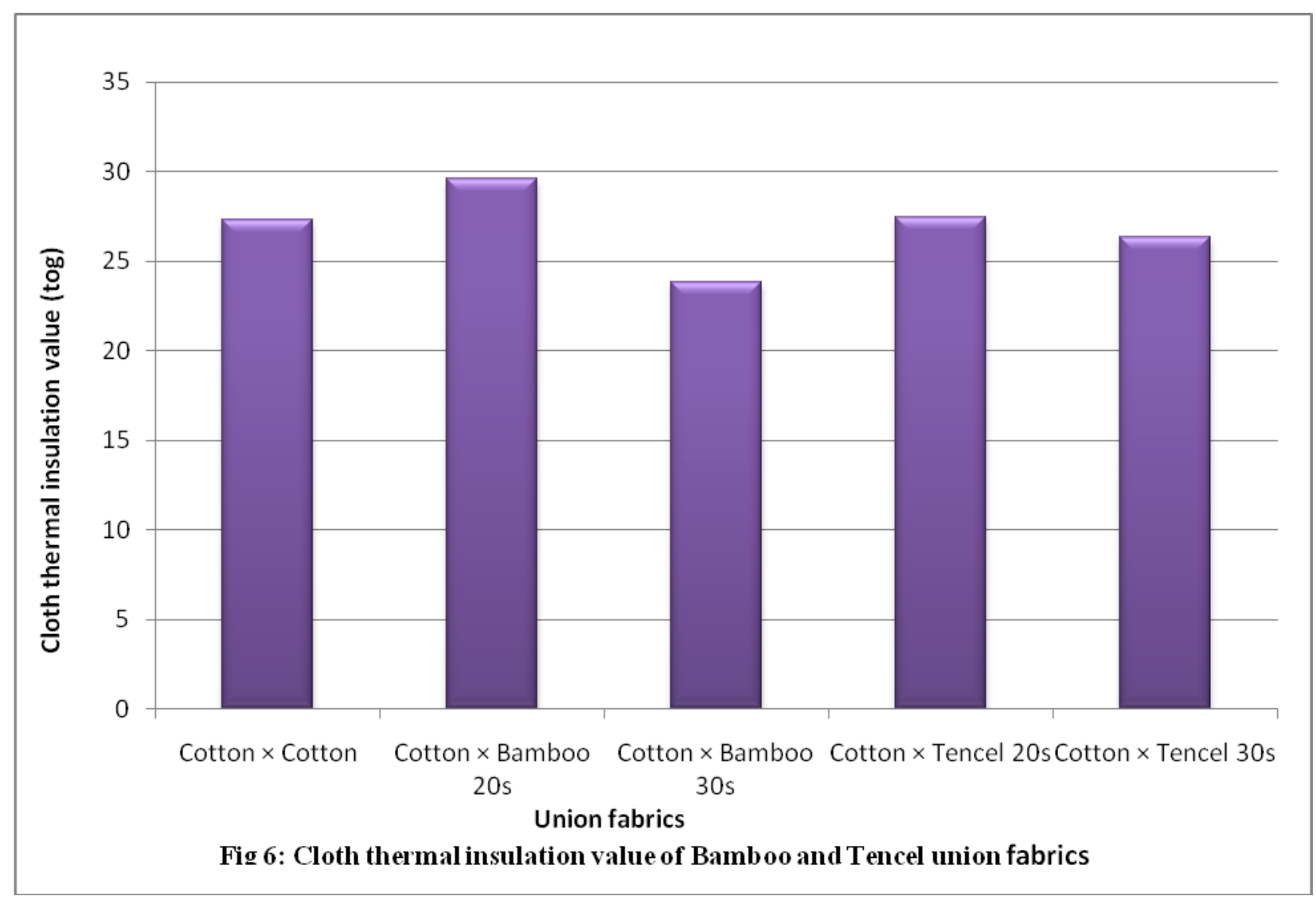




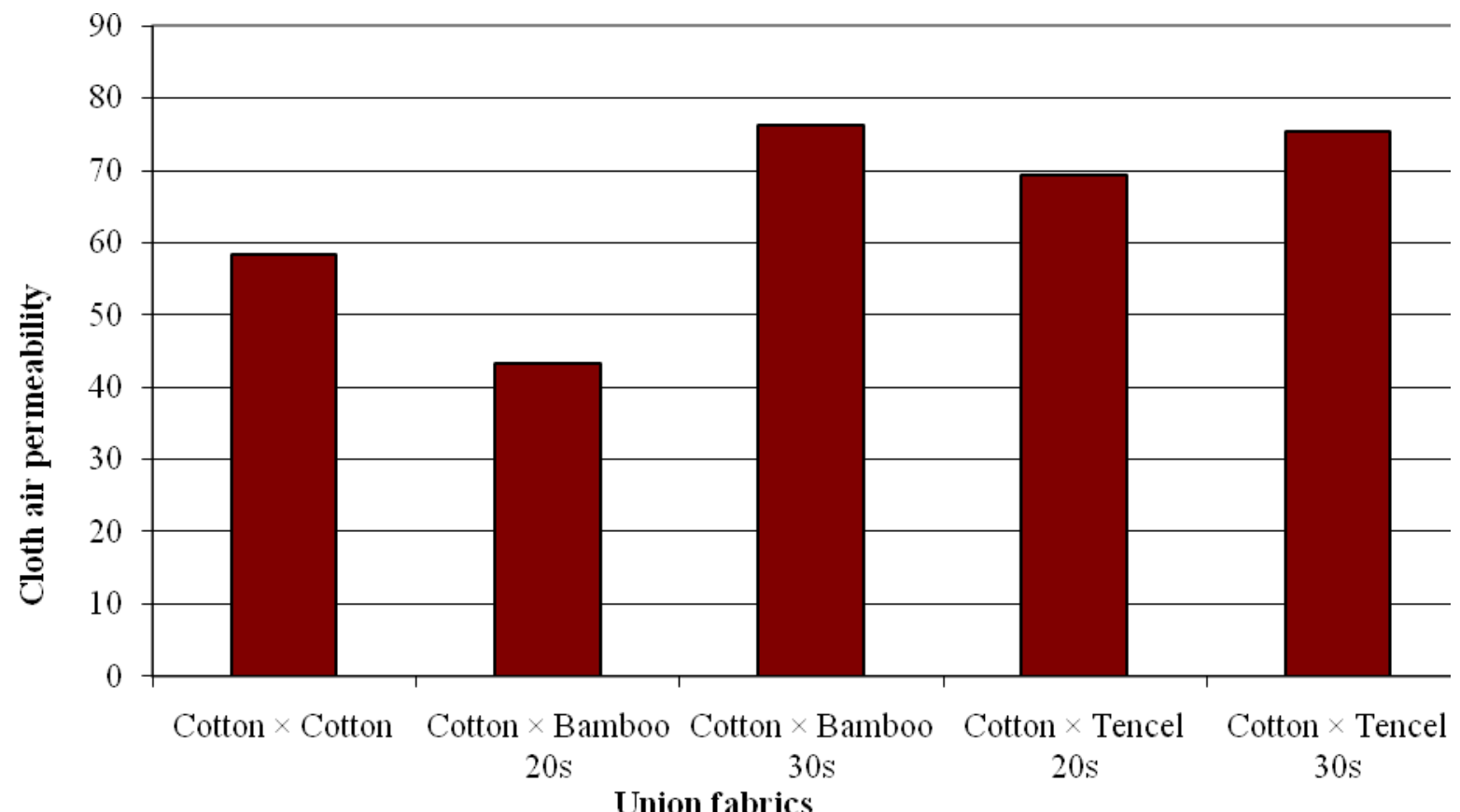

Fig 7: Cloth air vermeabilitv of cotton $\times$ bamboo/tencel union fabrics

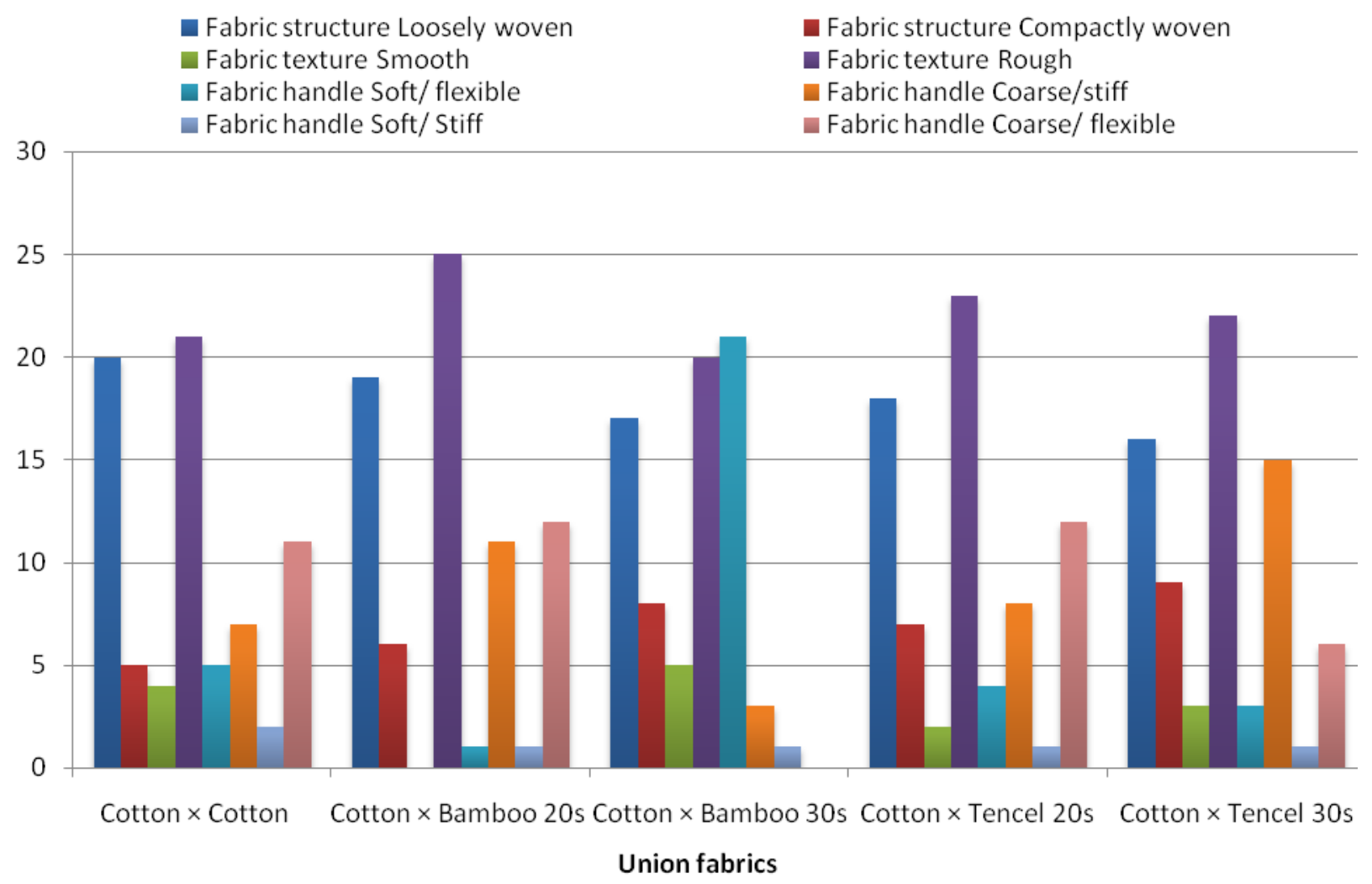

Fig 8: Textile expert's opinion on fabric structure and tactile properties of developed union 


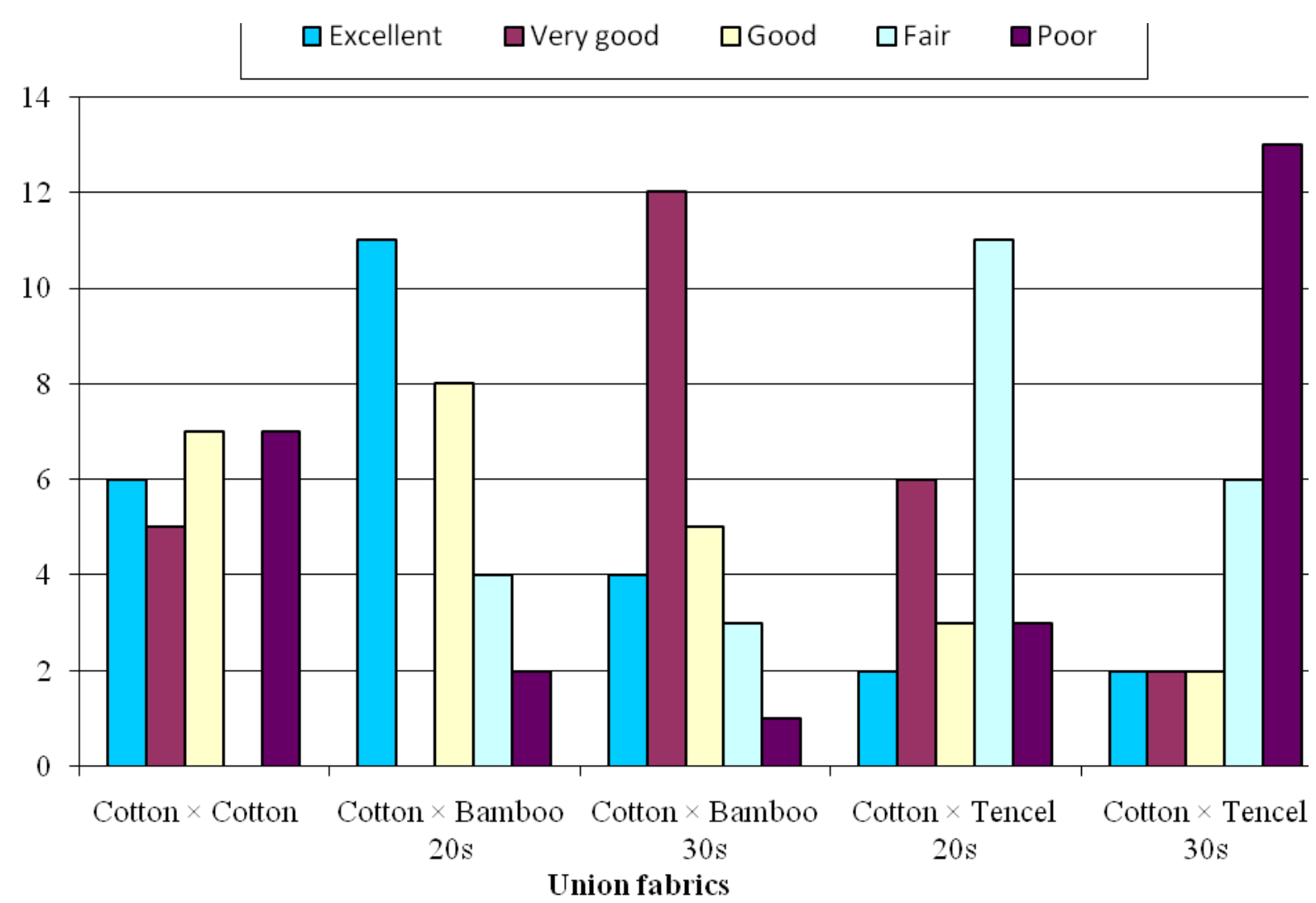

Fig 9: Preference of the developed union fabrics by textile experts

The results presented in Table 10 and Figure 7 depicted that, cotton $\times$ bamboo 30s $(76.26$ $\left.\mathrm{cm}^{3} / \mathrm{cm}^{2} / \mathrm{sec}\right)$ and cotton $\times$ tencel 30 s $(75.28$ $\mathrm{cm}^{3} / \mathrm{cm}^{2} / \mathrm{sec}$ ) union fabrics attained highest cloth air permeability which may be due to the count (30s) and compactness of the weave. It can be stated that, higher the yarn count, finer the yarn thus allowing more air to pass through the interstice spaces of the fabrics. Further, loosely woven fabric creates more spaces for air to pass through the fabric structure thereby increasing the air permeability. On the other hand, union fabrics of 20 s count were less permeable to air because of the use of coarser yarns and compactly woven fabric structure.

It was found in Table 11 and figure 8 that majority of the respondents opined that, the cotton $\times$ cotton fabric $(80 \%)$ was loosely woven with a rough texture. This may be because of the coarser yarn count and maida starch applied to warp yarns before weft insertion in order to avoid entanglement of yarn and making the yarns to easily pass through the dent. Based on the fabric structure and texture, it was observed that the union fabrics were attributing a soft/flexible, coarse/stiff and coarse/flexible fabric handle property. This may be due to the loom on which the fabric was woven and the different yarn count of bamboo and tencel yarns which also contributes to the fabric handle.

Table 12 and figure 9 depicts the preference of textile experts for cotton union fabrics based on the fabric structure, texture and handle properties. It is noticed cotton $\times$ bamboo 30s union fabric was highly preferred as it was woven with coarser cotton yarn thus adding weight and making it more usable. 
A perusal of Table 13 indicates that, variable cost of Cotton yarns was found to be higher in cotton $\times$ cotton (400.00/-) fabrics in comparison to Bamboo (250.00/-) and Tencel (280.00/-) union fabrics as rate of cotton yarns per $\mathrm{kg}$ was higher when compared to Bamboo and Tencel yarns. Total cost of production of one meter of cotton $\mathrm{x}$ cotton fabric (946.6/-) was maximum when compared to bamboo and tencel union fabrics as cotton yarns were the costliest yarns among the five types of yarns used in the study.

In conclusion, a union fabric is a textile fabric, which is woven using two different yarns in warp and weft direction to get a new fabric having the properties of both the yarns. Union fabric enables the weavers to combine two different sets of yarns so that good qualities are emphasized and poor qualities are minimized, thereby having the fabrics with better functional properties. Bamboo and Tencel union fabrics being user friendly, ecofriendly is of great use in medical textiles too.

\section{References}

Booth, J. E., 1996, Principle of textile testing: An introduction to physical methods of testing textile fibres, yarns and fabrics. CBS Pub. Distri., New Delhi, pp. 209253.

Kulkarni, A., Mahale, G. and Kariyappa, 2011, Physical properties of developed viscose rayon and eri silk union fabrics. Karnataka J.Agric Sci., 24(4): 506-509.

Majumdar, A., Mukhopadhyay, S., Yadav, R. and Mondal, K. A., 2011, Properties of ring-spun yarns made from cotton and regenerated bamboo fibres. Ind. J. Fib. Tex. Res., 36 (1): 18-23.

Prakash, C., Ramkrishnan, G. and Koushik, V. C., 2011, Effect of blend ratio on quality characteristics of bamboo/cotton blended ring spun yarn. J. Sci. Tech., 6 (2): 67-71.

Rashmi, P., 2016, Value addition to silk floss. M.Sc. Thesis, Univ. Agric. Sci. Dharwad, Karnataka (India).

Sarvanan, K. and Prakash, C., 2008, Bamboo fibres and their application in textiles. Indian Textile Journal., 15(3): 137-140.

\section{How to cite this article:}

Renuka Medar and Geeta Mahale. 2020. Functional Properties of Bamboo and Tencel Union Fabrics. Int.J.Curr.Microbiol.App.Sci. 9(06): 3851-3867.

doi: https://doi.org/10.20546/ijcmas.2020.906.455 